\title{
Norois
}

Environnement, aménagement, société

\section{Robert CHAPUIS, Besançon, un vignoble millénaire}

\section{Éric Rouvellac}

\section{(c)enEdition \\ Journals}

Édition électronique

URL : https://journals.openedition.org/norois/9707

DOI : $10.4000 /$ norois. 9707

ISSN : $1760-8546$

\section{Éditeur}

Presses universitaires de Rennes

\section{Édition imprimée}

Date de publication : 30 juin 2020

Pagination : 111-112

ISBN : 978-2-7535-8119-7

ISSN : 0029-182X

\section{Référence électronique}

Éric Rouvellac, «Robert chapuis, Besançon, un vignoble millénaire », Norois [En ligne], 254 | 2020, mis en ligne le 30 juin 2020, consulté le 05 janvier 2023. URL : http://journals.openedition.org/norois/9707 ; DOI : https://doi.org/10.4000/norois.9707 


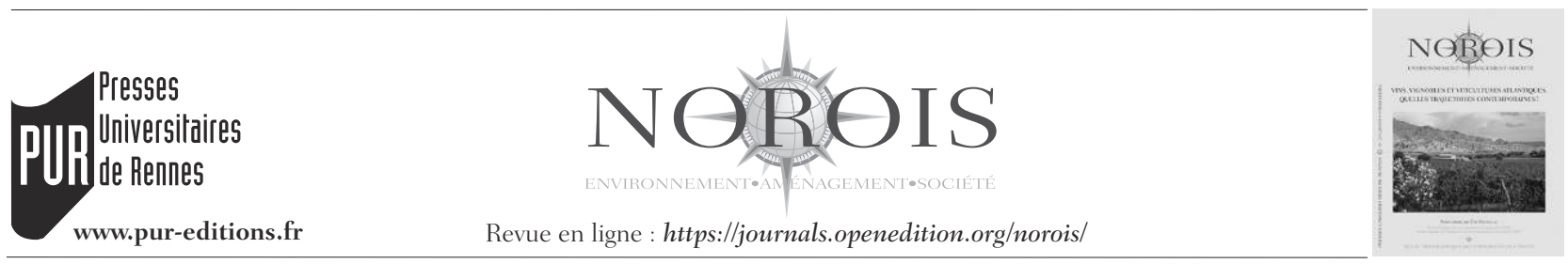

\section{COMPTE RENDU BIBLIOGRAPHIQUE}

Robert Chapuis, en collaboration avec Patrick Mille, Besançon, un vignoble millénaire, Paris, L'Harmattan, 2019, 204 p.

Cet ouvrage présente une étude historique de l'évolution de la vigne et de la production de vin dans l'agglomération de la ville jurassienne de Besançon, de la deuxième moitié du Moyen Âge à aujourd'hui. Il suit un plan historique classique qui s'appuie sur les phases générales de l'histoire de la vigne.

Le livre s'organise en cinq grandes parties, centrées surtout sur l'ère moderne et le XIX ${ }^{\mathrm{e}}$ siècle, apogée viticole de la région, mais aussi du reste de l'Europe. Le vignoble médiéval est l'apanage de l'Église avant que celui-ci ne se sécularise aux $\mathrm{XVI}^{\mathrm{e}}$ et $\mathrm{XVII}^{\mathrm{e}}$ siècles, avant de se banaliser avec la révolution des transports au XIX ${ }^{\mathrm{e}}$, et d'être précipité dans l'oubli avec le coup de grâce du phylloxéra. À noter les tentatives de replantations et de mises en valeur du patrimoine vitivinicole qui voient le jour ces trente dernières années. L'ouvrage finit sur une note positive.

Le propos ne tombe pas dans le travers de chercher des ancêtres les plus anciens possibles, y compris comme dans bien des ouvrages traitant de régions viticoles célèbres. Il s'appuie sur des documents, archives et cartes qui font qu'on ne remonte guère au-delà du bas Moyen Âge, ce qui donne déjà une épaisseur historique conséquente et montre la rigueur scientifique de ne pas extrapoler des choses difficilement prouvables. Ce souci des sources donne un point fort à l'ouvrage, avec la volonté de donner une place au patrimoine lié à la viticulture et sa préservation, aux travaux vitivi-

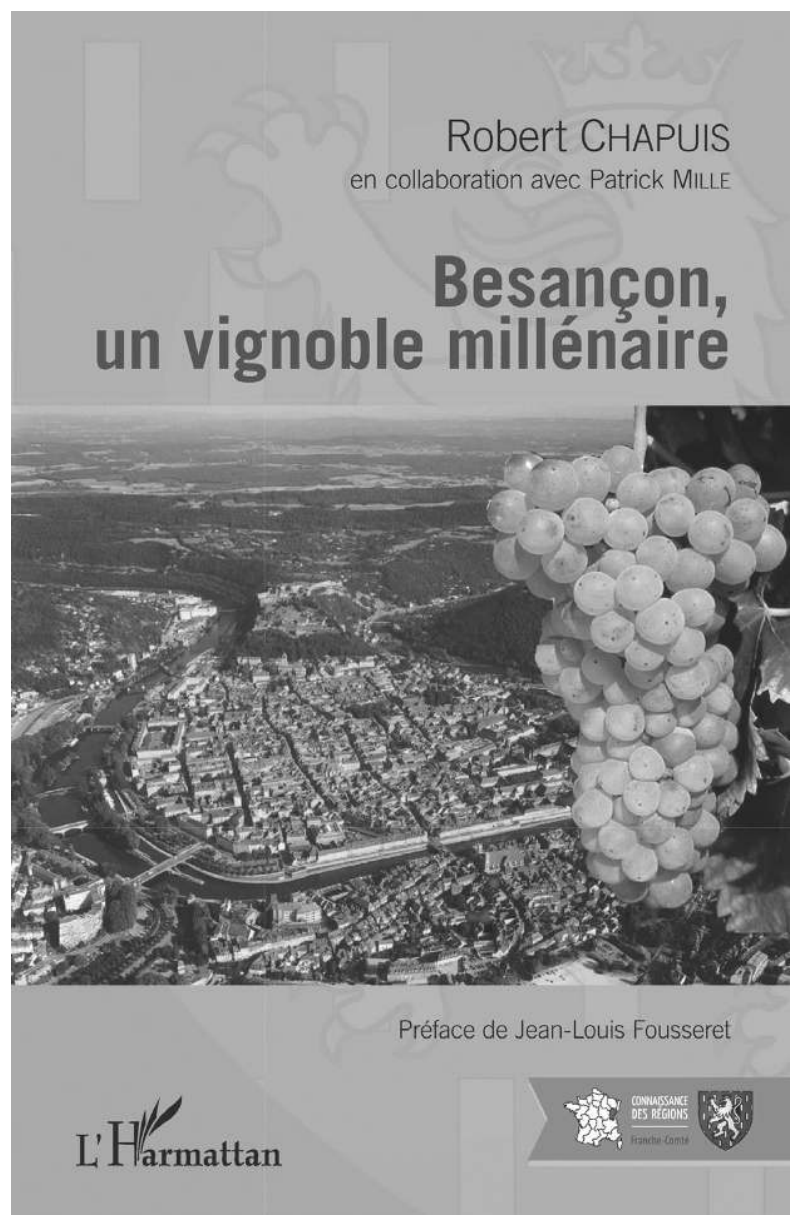

nicoles, à l'outillage, l'architecture, aux traces des aménagements de parcelles... 
Cet ouvrage bien écrit et richement illustré a l'avantage de mettre l'histoire et la géographie vitivinicole en dehors des sentiers battus, en indiquant que bien des contrées étaient, avant le phylloxéra, la Révolution industrielle et l'exode rural, porteuses ancestrales de vignes, de vins, de savoir-faire, d'une économie qui ont structuré le paysage. Ceci à travers un focus sur un territoire que le grand public n'associe pas à première impression à la viticulture, la région de Besançon.

Éric Rouvellac

Université de Limoges 